\title{
A Review on Lepa Kalpana in Dadru W.R.T. to Brihatrayi and Laghutrayi
}

\author{
Lalita Sharma*, Sudama Singh Yadav** \\ *Junior Resident-3(PG-Scholar), Department of Samhita and Sanskrit, Faculty of Ayurveda, Institute of Banaras \\ Hindu University \\ **Assistant Professor, Department of Samhita and Sanskrit, Faculty of Ayurveda, Institute of Banaras Hindu \\ University
}

Corresponding Author: Lalita Sharma

\begin{abstract}
Skin is the outermost covering of body and the largest organ of the integumentary system. Skin diseases are major health problem with emotional and psychological burden on patients. In Ayurvedic classics, almost all the skin diseases come under the broad heading of Kushtha. Dadru is a type of Kushtha which can be correlated with Tinea infection (fungal infection) in modern science. Three genera of dermatophytes infect skin i.e. Trichophyton spp, Epidermophyton spp and Microsporum spp. Ayurveda describes a multitude of treatment modalities for skin diseases in relation with various types of kushtha. One of them is the topical use of medicaments over the skin for topical absorption which allows faster absorption and better management of skin diseases.

Lepa kalpana is a herbal or herbo-mineral drug for topical use. Although lepa is an important therapy in various diseases but it is highly useful specifically in dermatological diseases. This review describes different lepas which are especially mentioned for Dadru in doctrines of Ayurveda.
\end{abstract}

Keywords: Dadru, Kushtha, Lepa kalpana, Skin diseases

\section{INTRODUCTION}

Ksustha has been broadly classified into two categories i.e. Mahakushtha and Kshudrakushta. According to Acharya Charaka, Dadru is a type of kshudra kushtha which has dominance of Vata and Pitta dosha. But Acharya Sushruta considered it as a type of mahakushtha with predominance of Vata and Kapha dosha. Vagbhata also followed the views of Acharya Sushruta. In Bhavprakash and Madhava Nidan, it is described under the heading of kshudra kushtha.

According to Ayurveda classics, viruddha ahara is considered as the chief etiology of all types of kushtha. Due to the consumption of viruddha ahara, disturbance in various mechanisms of digestion, metabolism and transport of nutrition in the body occurs. Due to mandagni undigested ahara results in the formation of aama which acts as an antigen causing reaction in the skin and resulting in allergic reactions in the skin. According to modern medical science, skin diseases are either due to allergic reactions or infections. Various ingredients used in lepa kalpana have the ability to correct the above mentioned pathology of Dadru.

The treatment of diseases as mentioned in Ayurveda is of three types viz1) Antahparimarjana

2) Bahihparimarjana

3) Shastrapranidhana

Out of these three, lepa is included in Bahihpramarjana chikitsa. Acharya Charaka has mentioned about lepa kalpana in a separate chapter titled "Aragvadhiya adhyaya". Whereas lepa kalpana is described in Sushruta samhita, Ashtanga 
Hridya and Sharngdhar samhita also. The formulations that are prepared by grinding of adra dravyas (wet ingredients) or by shuska dravyas with addition of liquid media for topical use are known as lepa. Wherever the treatment of kushtha has been described in texts of Ayurveda, description of lepa kalpana has also been done without any exception.

\section{MATERIAL AND METHOD}

In this article, review of relevant literature has been carried out from Charak samhita, Sushruta samhita, Ashtanga Hridya and Sharngdhar samhita, Bhavprakash, and Madhava Nidana.
Research and review articles from national and international journals regarding literature review have also been assessed. Lepa kalpana and absorption \& metabolism of lepa(drug):

Absorption and metabolism of lepa (drug) is a collective work of Bhrajaka pitta, Saman and Vyana vayu and slesaka kapha. Bhrajaka pitta metabolizes the active principles of drugs that have been applied over the skin with the support of saman and vyan vayu.

According to modern medical science, lepa kalpana can be understood in form of transdermal drug delivery system. Transdermal drug delivery system:

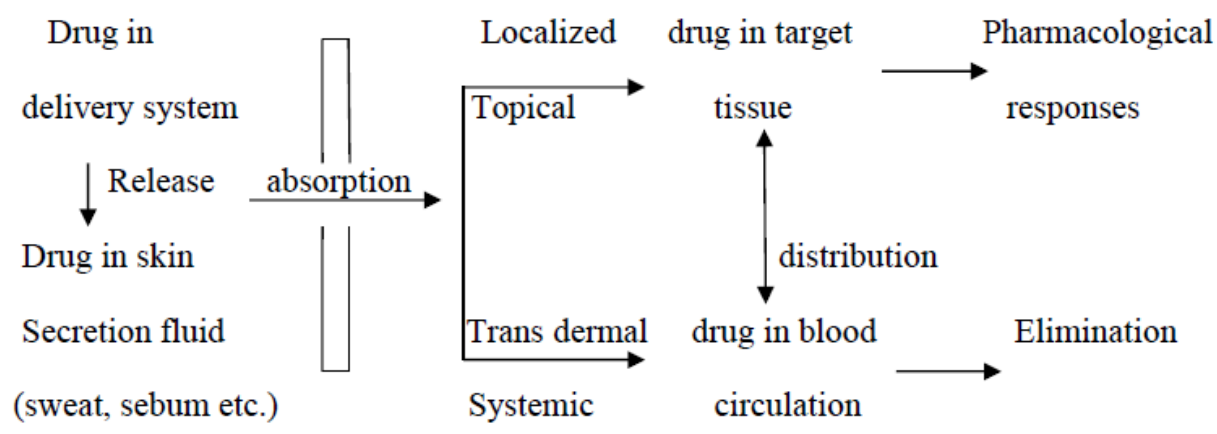

$\mathrm{Ph} 4.5-5.5$

Fig 1: Percutaneous absorption of drug for localized therapeutic action in the skin tissue or for systemic medication in the tissue remote from the site of topical drug application.

\section{Lepa in Dadru:}

According to Acharya Sushruta there are three types of lepa kalpana :

1) Pralepa

2) Pradeha

3) Aalepa

Aalepa is suitable for Dadru as per symptoms of the disease. Aalepa stands in between pralepa and pradeha. Aalepa posseses the property of pacifying and restoring the vitiated Rakta and Pitta to their normal condition.

According to Sharngdhara, there are three types of lepa classified according to their karma:

1. Doshaghna (anti-doshika)

2. Visaghna (anti-poisonous)

3. Varnya (for healthy and glowing skin)

So doshaghna lepa can be used in diseases like dadru.

\section{Specifications of lepa:}

Acharya Sushruta affirms that the pramana of lepa should be as "mahishadracharmotsedha" (newly flared skin of buffalo). The thickness of buffalo's skin may be considered as 2.8 to $3.2 \mathrm{~mm}$. Sharngdhara specifies the thickness of doshaghna lepa as $3 / 4$ angula i.e. $0.48 \mathrm{~cm}$ approx.

\section{Duration:}

Lepa acts to treat the disease (Dadru) as long as it contains humidity whereas harms the skin when it gets dry.

Lepa kalpana mentioned in Laghutrayi and Brihatrayi especially for Dadru: 


\section{Charaka Samhita:}

\begin{tabular}{|c|c|c|}
\hline Lepa & Ingredients & Media \\
\hline 1 & $\begin{array}{l}\text { Amaltash, chakramarda, karanja, } \\
\text { adusa, guduchi, haldi and } \\
\text { daruharidra }\end{array}$ & \multirow[t]{6}{*}{$\begin{array}{l}\text { Gopitta and } \\
\text { mustard oil }\end{array}$} \\
\hline 2 & $\begin{array}{l}\text { Gandhviroja, devdaru, khadira } \\
\text { dhava, neema, vayavidanga and } \\
\text { kanera }\end{array}$ & \\
\hline 3 & $\begin{array}{l}\text { Bhojpatra granthi, rason, sireesh, } \\
\text { lomasha, guggulu, sahijana }\end{array}$ & \\
\hline 4 & $\begin{array}{l}\text { Vanatulasi, kutaja, saptaparna, } \\
\text { peelu, kustha, sumanhpravala }\end{array}$ & \\
\hline 5 & $\begin{array}{l}\text { Vacha, harenu, nishotha, } \\
\text { dantimula, bhallataka, gairika, } \\
\text { anjana }\end{array}$ & \\
\hline 6 & $\begin{array}{l}\text { Mainshila, pinda hartala, } \\
\text { gṛhihaduma, ela, kasisa, lodhra, } \\
\text { arjuna, musta, sarja }\end{array}$ & \\
\hline $\begin{array}{l}7 \text { Eḍagajadi } \\
\text { lepa }\end{array}$ & $\begin{array}{l}\text { Chakramarda, } \\
\text { saindhava, sarsapa }\end{array}$ & $\begin{array}{l}\text { Sauviraka } \\
\text { (kanjika) }\end{array}$ \\
\hline
\end{tabular}

\section{Suśhruta Samhitā:}

\begin{tabular}{|l|l|c|}
\hline Lepa & Ingredients & Media \\
\hline 1 & $\begin{array}{l}\text { Laksha, Kushtha, sarsapa, shriniketa, haridra, } \\
\text { shunthi, maricha, pippali, seeds of } \\
\text { chakramarda, seeds of moolaka }\end{array}$ & Takra \\
\hline 2 & $\begin{array}{l}\text { Saindhava, seeds of chakramarda, guda, } \\
\text { nagkesara, rasota }\end{array}$ & Kaitha \\
\hline 3 & $\begin{array}{l}\text { Svarnkshiri, amaltasha, shirisa, neema, sarja, } \\
\text { vatsaka, sajkarna }\end{array}$ & - \\
\hline
\end{tabular}

\section{Aṣțānga Hṛdya:}

\begin{tabular}{|l|l|c|}
\hline Lepa & Ingredients & Media \\
\hline $\begin{array}{l}\text { Mustadi } \\
\text { lepa }\end{array}$ & $\begin{array}{l}\text { Musta, lodhra, guduci, kampillaka, sanga, } \\
\text { kantaka, teri, Kșțha, gandhoplepa, } \\
\text { sarjaso,vidaṅga, manaḥsilā, karvīrtvaka. }\end{array}$ & - \\
\hline
\end{tabular}

\section{Bhavaprakasha :}

\begin{tabular}{|l|l|l|}
\hline Lepa & Ingredients & Media \\
\hline 1 & $\begin{array}{l}\text { Kushtha, krimighna, dadrughna, nisha, } \\
\text { saindhava }\end{array}$ & Amla \\
\hline 2 & $\begin{array}{l}\text { Durva, abhaya, saindhava, cakramarda and } \\
\text { kutherka }\end{array}$ & $\begin{array}{l}\text { Takra, } \\
\text { kanjika }\end{array}$ \\
\hline 3 & $\begin{array}{l}\text { Paste of gandalika grass, siddharthaka, } \\
\text { snuhipatra- all are equal parts, dadrughna- } \\
\text { double quantity and cowdung }\end{array}$ & $\begin{array}{l}\text { Eight part } \\
\text { of takra }\end{array}$ \\
\hline
\end{tabular}

\section{Shrngdhar samhita:}

\begin{tabular}{|l|l|l|}
\hline Lepa & Ingredients & Media \\
\hline 1 & $\begin{array}{l}\text { Seeds of prapunnata, bakuchi, } \\
\text { sarshapa, tila, kushtha, two } \\
\text { nishas, musta }\end{array}$ & Takra \\
\hline 2 & $\begin{array}{l}\text { Hemakshari, vidanga, } \\
\text { darada(hingula), gandhaka, } \\
\text { dadrughana, kushtha, sindura }\end{array}$ & $\begin{array}{l}\text { Fresh juice of leaves } \\
\text { of dhatura, nimbi, } \\
\text { and tambul }\end{array}$ \\
\hline 3 & $\begin{array}{l}\text { Durva, abhya, daindhav, } \\
\text { chakramarda and kutheraka }\end{array}$ & Takra \\
\hline 4 & $\begin{array}{l}\text { Durva and nisha } \\
\text { Sidharh, rajni, kushtha, } \\
\text { prapunnada, tila }\end{array}$ & $\begin{array}{l}\text { Katutaila (mustard } \\
\text { oil) }\end{array}$ \\
\hline 5
\end{tabular}

\section{DISCUSSION}

Lepa kalpana is given prime importance in management of kushtha (skin diseases). Various types of lepa are described for the treatment of Dadru. Various ingredients which pacify the vitiated doshas and those good for healthy skin, should be used for the preparation of lepa. There is dominance of Pitta- Kapha in Dadru according to Charaka and VataKapha according to Susruta and Vagbhata. Since there is difference of opinion amongst various acharyas regarding this disease (Dadru) in terms of doshik involvement, therefore scholars have mentioned different drvyas according to their own opinion regarding doshik involvement. Used media for preparation of lepa kalpana in dadru are mainly amla dravyas like kanji, takra, gopitta, amla, kaith etc.

\section{CONCLUSION}

Skin being the outermost covering of the body serves as an important component in terms of protective as well as cosmetic purpose. It is therefore essential to treat the skin diseases in time for better prognosis and to conserve its cosmetic function also. Majority of patients prefer to get their skin diseases treated with topical administration of drugs rather than their systemic use. Lepa kalpana is an excellent scientific method of introducing the active principles of drugs to the target cells for a quick and effective healing process. It utilizes a combination of herbal or herbomineral drugs to prepare a formulation to treat Dadru which is a prominent skin condition in dermatological OPD patients. Ayurveda can definitely prone to be a boom in the proper and effective management of this kind of skin condition in today's time.

Acknowledgement: None

Conflict of Interest: None

Source of Funding: None 


\section{REFERENCES}

1. P. Kashinath Pandey and Dr. Gorakhnath Chaturvedi, Caraka samhita, vol.1, Chaukkhamba Bharti Academy, Varanasi 2013 page no. 59-60

2. P. Kashinath Pandey and Dr. Gorakhnath Chaturvedi, Caraka samhita, vol.2, Chaukkhamba Bharti Academy, Varanasi 2015 page no. $248,250,252,268$

3. Kaviraja Ambikadutta Shastri, A.M.S. Shushrut samhita, Vol.1, Chaukhambha Sanskrit Samsthan ISBN: 978-81-89798-192 voi.1, edition 2015 page no. 97, 320

4. Kaviraja Ambikadutta Shastri, A.M.S. Shushrut samhita, Vol.1, Chaukhambha Sanskrit Samsthan ISBN: 978-81-89798-192 voi.1, edition 2015 Chikitsa Sthana page no. 64

5. Bhishagacharya Harishashtri Pradakara Vaidya, AstangaHridayam, Chaukhambha Orientalia, Varanasi, ISBN: 978-81-7637017-2 edition 2019 page no. 524, 525, 716

6. Prof. K.R. Srikanth Murthy, Chaukhambha Orientalia, Varanasi, Fourth Edition 2001,
Uttara Khanda Chapter 11 page no. 235, 241

7. Bhavprakasha of Bhavamishra English translation Translated by Prof. K.R. Srikanth Murthy, Krishnadas Academy, Varanasi, ISBN: 81-218-0033-1 (vol.2), edition: reprint 2002 , Madhya Khanda page no. 601,620

8. Illustrated Synopsis of Dermatology and Sexually Transmitted Diseases, Neena Khanna, $6^{\text {th }}$ Edition, Elsevier India Private Limited, page no. 290

9. Transdermal Delivery of Drugs, edited by Agis F Kydonieus and Bret Berner. Vol.1, CRC Press Floida, 1987; page no.83.

10. Sud Khyati Shusanth, Functional Overview of the formulation used for tvak vikaras, international journal of ayurvedic and herbal medicine IJAHM 4:2(2014) 1448-1455

How to cite this article: Sharma L, Yadav SS. A review on lepa kalpana in dadru W.R.T. to brihatrayi and laghutrayi. Int $J$ Health Sci Res. 2021; 11(4): 102-105. DOI: https://doi.org/ 10.52403/ijhsr.20210413 